\title{
Reframing test accommodation practice on English high-stake examination in Indonesia
}

\author{
Imam Khasbani* \\ Teaching English to Speakers of Other Languages (TESOL), \\ University of Bristol, United Kingdom \\ *Corresponding Author: \\ Email: imamkhasbany.2017@my.bristol.ac.uk
}

\begin{abstract}
The need to provide equal education access through an inclusive system to students with difficulties (henceforth SwD) has witnessed a substantially growing interest in the last recent years. As a standard practice of education and accountability system is inseparable, the need to include SwD in largescale assessments has also become a central interest of many pedagogical practitioners around the world. This situation has later initiated the invention of test accommodation. With their challenges and difficulties, SwD are not expected to take part in the regular procedure of assessments. This paper, with regard to the above assertions, seeks to examine the accommodation practice in Indonesian educational system. It will primarily focus on analysing the types of accommodation applied in the country's English high-stake assessment and the evaluation of the effectiveness of the ongoing practice. Contrary to common belief, accommodation in a language test is not exclusively aimed to accommodate students with mobility and cognitive challenges. Test accommodation is also aimed at helping students who face difficulty in the language of classroom instructions. However, due to the limited space reason and the fact that the phenomenon of learning difficulties caused by the inability of students to understand the language of instruction is uncommonly reported in Indonesian educational settings, this paper will primarily focus on the accommodation issue for students with physical and mental difficulty. Apart from highlighting on the history of test accommodation as well as the related issues, this paper will cover the nature of Indonesia's practice towards test accommodation and discuss its real implementation. Further recommendations on how the test accommodation should be conducted in Indonesia educational settings will be discussed.
\end{abstract}

Keywords: Test Accommodation; National Examination; Student with disabilities; Special Education; Test Accommodation

Received:

28 February 2019
Revised:

7 August 2019
Accepted:

12 August 2019
Published:

31 August 2019

\section{INTRODUCTION}

\section{Defining the Complexion and Issues of Test Accommodations}

The need to provide equal access for SwD and fight discrimination conducts in education have been a centre of attention for educational initiatives around the world. As education and assessment draw a close and reciprocal 
Khasbani, EduLite: Journal of English Education, Literature, and Culture

relationship where one cannot exist without another and the fact that highstakes assessments often act as the main educational accountability and primary gatekeeper of students' access to higher education and distribution of employment (Bolt \& Thurlow, 2004), ensuring inclusive students to take part in national assessment is also of importance. It has been argued that SwD should enjoy the same privilege of high-stake examination and this conception has led to the emergence of test accommodation. Test accommodation is commonly defined as an adjustment of a standard test construct to ensure an equal access and "the fair treatment of students with special needs" in the academic assessments (Lovett, 2010, p.612; Pitoniak \& Royer, 2001).

The main idea of providing accommodation in academic tests is to adjust the level of playing field while at the same time also to facilitate SwD's comprehension to accurately comprehend test instructions and remove unnecessary testing barriers whose existence might potentially hinder the assessment from reflecting the valid picture of students' real competence (Abedi, 2009). In its general practice, test accommodation can take many different formations. As elicited by Lang et al. (2005) the adjustment can take place in the test presentation- using different medium or ways of test presentation (i.e., by using larger text or screen reader), response- giving alternative way to provide an answer (i.e., giving oral answers instead of writing response), timing and setting- putting students in an untimed testing condition and specialised rooms.

It has been widely reported that test accommodation brings a positive effect to SwD. Elliott and Marquardt (2004) maintain, after conducting an empirical study on 97 eighth-grade students both with and without disabilities, that the majority of their participants showed a significant gain in achievements after they were provided with a test accommodation. As the accommodation offered in the study was in the form of time extension, the improvement on students' scores can be rationally thought to result from the psychologically and emotionally state of SwD that were positively affected by the extended time accommodation. As SwD usually take more time to engage in conceptual information and process the written instructions (Lambert \& Tan, 2017), having extra more time appears to give them more comfortable and less stressful feeling that can help them process more questions and provide more accurate answers. However, despite the facilitative feature it offers, accommodation practice does not go unchallenged.

Test accommodation are often blamed for their possibility to create a validity and fairness gaps among test participants. Regarding the validity issue, one of commonly raised questions, as stated by Phillips (1994) and Sireci et.al (2005), is around the extent to which modified assessments can give a bona fide score interpretation that test providers and educational institutions could utilize to tell the actual ability of a group of accommodated students. Those irresolute about the validity level of test accommodations are often of the opinion that alterations on a standard test can be highly possible to fallaciously inflate and deflate the achievement scores. In addition to that, test accommodations are also blamed for creating a fairness issue where the accommodated students are often perceived to receive a more significant benefit in the assessment compared to their unaccommodated counterparts or vice versa. A fair accommodation as argued by Li and Suen (2012) should only 
exert a corrective effect to the accommodated students and if provided to the non-accommodated participants will bring no significant change. In practice, however, test accommodations sometimes produce contradictory results. The studies on linguistic modifications on mathematics examinations by Abedi and Lord (2001) and Abedi, Lord, and Hofstetter (1998), for example, exhibited inconsistent representations on test fairness. While the former study reported that language adjustment had only benefited students with mathematics difficulties, socio-economic disadvantage, and English language barrier; the latter witnessed the simplified language applied in the mathematics test has exerted a considerable advantage to both students with and without disabilities. And if referred to the previously stated definition of fair assessment, the linguistic adjustment in the study of Abedi, Lord, and Hofstetter (1998) cannot be regarded as a fair accommodation because the non-accommodated students were found to also significantly enjoy the advantage of the adjustment.

Taking all the benefits and issues around test accommodation into account, it is evident that at a general level there is no uniform consensus toward the effectiveness of accommodation practices in providing both equal access and representative score interpretations in the assessment system. However, as argued by Cahalan-Laitusis (2004), Stangvik (2010), and Ainscow (2012), the regulation of test accommodation is considerably varied in nature; its conceptual framework and practice do not take shape in a vacuum and are always differently adjusted depending on the complexity of society and the nation's culture. Therefore, the practice of test accommodations in Indonesiathe context on which this paper will focus-might set forth different conditions. Hence, to reveal the real practice this paper will begin by introducing the inclusive education in the country and the current state of its high-stakes examination.

\section{METHOD}

This article employed literature study approach. Various resources such as books and journal articles were utilised to gather all relevant information and build on discussion on test accomodation for students with difficulties and the current practices of accomodation in Indonesia's national examination.

\section{RESULT AND DISCUSSION}

\section{A Short Narrative of Inclusive Education System and Test Accommodation in Indonesia}

The past several decades, right after the enactment of inclusive proclamations such as the 1948 Universal Declaration of Human Right and the Salamanca Statement, have witnessed the growing interest of worldwide education sectors to provide accessible education for all students regardless their physical or intellectual conditions (Lindahl, 2006). Following the trend, Indonesian government issued legal mandates reflected in the Indonesian National Regulation No. 20 (2003), which pronounced that the country does not uphold and acknowledge discrimination practice in its education sector and that all children have the same right of education in every stage of their life. This 
Khasbani, EduLite: Journal of English Education, Literature, and Culture

regulation, which at the same time also demands that every region in Indonesia have at least four inclusive institutions (Sheehy, Budiyanto, Kaye, \& Rofiah, 2017), has initiated the increasing phenomenon of children with disabilities to enter schools. In practice, parents of children with disabilities are given an alternative to either send their children to the regular school (only if the children do not exhibit any classroom disruptive behaviours or do not possesses severe immobility) or put them in a specialised school designed exclusively for SwD that the local government labels as Sekolah Luar Biasa (Purbani, 2013; Aprilia, 2017). However, despite the supportive regulation, the practice of inclusive educations in Indonesia does not escape from public evaluations, which are often aimed at the problematic aspect of Guru Pendamping Khusus (Special Supervising Teachers/ SST), enrolment rate, school facilities, and evaluation system.

The first problem pertains to SST administration. As put forward by Indriawati (2013), SST possess a vital role in maintaining and evaluating the process of inclusive educations. The Ministry of Education's decree of 2009 number 70 article 10 declares the obligatory status of SST's presence on every inclusive school in Indonesia. However, the inclusive education statistic report in 2016 indicated that the number of SwD and SST have not yet shown a coequal representation (Ministry of Education, 2016). With the total of SwD reaches 24985 in number and there are only 1101 SST available, one could argue that the teacher allocation cannot achieve the minimum standard regulation. The report data exhibits that in some province in Indonesia such as Bangka Belitung and South Sumatra there is only one supervising teacher for all available inclusive institutions (Ministry of Education, 2016).

The next problem is the enrolment ratio. Although the inclusive regulations have successfully increased the number of new entrants, the rate has not yet met the national expectation. As stated in the in UNESCO's (2008) report, Indonesia's government has targeted $95 \%$ of children with disabilities population to participate in primary and secondary school level. However, the Ministry of Education's (2017) annual statistics reported that there are only 121,244 SwD studying in all over schools in Indonesia. The figure, as one can easily notice, has not been up to par and reflects only a small fraction; given the total population of people with disability according to Indonesia Ministry of Health (2014) is $2.45 \%$ of the total population or roughly more than 6 million in 2012 alone.

The last problem that often draws the public's attention and becomes this paper's focus is related to the inclusive school facilities and evaluation guidance. Poernomo's (2016) study of inclusive schools that was conducted in five provinces in Indonesia found that the both supporting (i.e., disable toilet) and learning facilities (i.e., braille books) for SwD were not equally allocated to the country's inclusive schools. Furthermore, interviews of the study revealed that the schools were not given enough guidance and support on the evaluation system. This episode has led to a situation where most of the teachers in the inclusive schools are uncertain of how they should assess their student. The lack of clear assessment procedure, however, does not only happen in the classroom level, as pointed out by Felicia and Ramli (2017) it also occurs in the country's high-stake or national examination. Therefore, as the following section shows, the lack of clarity on the accommodation practice 
has created a situation where there is a little evidence of appropriateness and effectiveness on national examination in Indonesia.

\section{The Accommodation Practices in the National Examination}

In Indonesia educational setting, national examination functions as a measuring tool to define the quality of students from all educational level as well as to acts as a prerequisite component of most university entrances in the country (Qudsyi \& Putri, 2016). Concerning its vital role, the national examination must be attended by both students with and without disabilities. The need of SwD to take part in this nationally-administered test is resonated in the Ministry of Education's (2009) decree No.70 article 10 which declares that all students in inclusive educational institutions must participate in the national examination. This regulation was later followed by Ministry of Education's (2015) decree No.9 which mandates that local authorities (in this case governor and provincial education office) are responsible for the administration of the national examination in every regular and inclusive school in their local region. The responsibilities are including the selection of schools as the test venue, the distribution of the test paper, the socialisation of the assessment, and the formation of the national examination technical procedure. While the regulations have indicated the government's commitment to provide fair educational access and assessment to SwD, they have not yet, as one can easily argue after reading the policy papers, implicitly stated the detailed regulation of the test accommodation. As will be described and evaluated in the following sections, the lack of a sound regulation has created an issue on test accommodation conduct and SwD further life and occupation.

\section{The Misconduct of Test Accommodations}

As the initial objective of accommodations is to promote state-wide assessment accessibility and retain the nature of its construct validity (Lovett \& Lewamdowski, 2014), it is essential for test providers to include suitable adjustments in their accommodation. The notion of accommodation suitability is of importance and should become the test makers' centre of attention because disabilities come in a variety of forms that require a different type of procedural alterations. The accommodation of students with hearing problems, for instance, will be greatly different from those with visual impairments. The practice of accommodation suitability has been conducted in several countries. In the United States, for example, through the country No Children Left Behind Act 2001 the government implicitly articulates that the form of accommodation given to students based on their impairment conditions. Although the administration is a district-level decision, which means each district is responsible for choosing what and how accommodation to be implemented, the district 's policy, as stated by Young and King (2008), is clear about the matter and "consistent with their state's policy" (p.2). This consistency, however, is not witnessed in Indonesia assessment system. Even though the regulation in Indonesia has emphasized the need of inclusive schools to take part in the standardised test, it did not come with clear guidance and as a result it has created a wide-ranging educational effect on inclusive educations. One of the commonly reported consequences is the misconduct practice of adjustments that takes shape in inappropriacy, 
Khasbani, EduLite: Journal of English Education, Literature, and Culture

inconsistency, and the absence of test accommodation format in the academic environments.

The examples of inappropriacy and inconsistency are what happened in some inclusive schools during the last year national examination. In 2017, several ninth grade students with hearing disability from Bali province schools reported that they faced difficulty in understanding the instructions and content of the tests (Mahendra, 2017). As argued by teachers in the schools, the language used in the test was too complicated and not straightforward for hearing disabilities students whose language development are much less advanced than their hearing counterparts. The teacher further argued that the government should have constructed the question by using more simple language to avoid this unnecessary problem. In the same year, Education Office in Banten province mentioned, as cited by Deslatama (2017), that students with hearing disability regardless the severity of their impairment will not be provided with additional teachers in the class whose presence will usually help them interpret unfamiliar terms by using sign language. However, a dissimilar policy was applied in inclusive school in Jambi province. The schools in this province put several additional teachers in the test room to help students with hearing and vision disability understand the questions and the content of the test (Antara, 2017). While the government has provided freedom to every region to regulate the test accommodation based on their educational setting situation, this inconsistency can not only encourage the presence of unnecessary barriers in the test but also raise a problem in society like the test reliability and fairness.

In addition to the inconsistency of the accommodation forms, the absence of test adjustment is also witnessed in Indonesian inclusive education. One of the cases took place in 2012 when a group of sightchallenged students in an inclusive school in Yogyakarta province had to deal with the situation where the government did not distribute braille question papers to the school despite the fact that the students had been trained to read this specialised printed paper months prior to national examination (Detik News, 2012). The students who were not prepared and in an unlikely situation to use regular test papers had to depend on the teachers' voice to answer the questions. In English test, teachers had to read all the texts and the questions while students sat quietly and listened. While it, in fact, helped students with getting the insight of the questions, one can problematise this practice as violence of test validity because students were not directly assessed based on the expected reading ability.

Responding to this occurrence, in 2012 Yayasan Mitra Netra-a local organisation that concerns on the equality of vision impaired children- sent queries to the stakeholders in the ministry of education. However, it was reported that they received a somewhat unsatisfactory and shocking reply. It was argued that because the number of students with visual impairment in Indonesia is small, it is financially impractical to provide them all with Braille question papers that can cost three million Rupiah in one set of paper question production (Yayasan Mitra Netra, 2012; Indrakrista, 2014). This situation, while widening the fairness gap between regular students and those with visibility challenges, can also result in the emergence of irrelevant accommodation practice, where SwD are provided with a test adjustment that 
they do not actually need and that do not help remove the construct-irrelevant barriers. And as a subsequent result, offering an accommodation that has no relevance with students' difficulties can result in a negative impact on their test performance and an unrepresentative result of the assessment (Abedi, 2017). The scores printed in the SwD graduation paper do not reflect the true ability of their learning performances.

\section{Social and Academic Implication of Test Accommodations}

The lack of clear regulation on how SwD will be assessed has created a farreaching consequent in both society and school level. In the society level, due to the unrepresentative result of assessment as a subsequent effect of irrelevant and unsuitable accommodation, the quality of SwD graduate is often not held accountable by the professional and academic system. It becomes an uncommon phenomenon in Indonesian occupational context where students from inclusive school-despite their true capability-are rejected from getting a job position because of their high-stakes examination scores (Ramdani, 2016). It becomes a difficult situation for them to find a job that they want because most companies will primarily refer to scores on graduation papers to decide the credibility of the applicant. The difficulty also happens when inclusive school leavers intend to continue their education to higher institutions. Christiyaningsih (2017), reported that because the passing grade-minimum scores that a student should achieve to get enrolled in a university- set by state universities in Indonesia is not adapted with the inclusive education system; many SwD find themselves incapable of reaching the minimum score and not admitted in the higher education institutions.

In addition to that, the study of Sunardi et.al (2011) found that the unsettled test accommodation has resulted in the seemingly increasing rate of school dropout. The dropout rate, as Sunardi et.al (2011) further asserted, is arguably to be rooted in a phenomenon where only special need students with 'normal intellectual' (p. 8) will be facilitated to take the examination. This assertion apparently receives supports from many researchers. Ediyanto et.al (2017), for example, reported in their study that the education curriculum has required SwD to participate in the national examination but "the requirement is that students with special needs have no mental retardation or severe disability" (p.113). Although the indicator of 'normal intellectual' is somewhat impressionistic, problematic and potentially discriminative because it appears to be not provided with a clear-cut definition by the government, it still successfully thrives and becomes the standard reference for most inclusive education practitioner to decide whether their students should be included in the national assessment process. Under this circumstance, SwD who do not fall under this 'normal' intellectual category are often time excluded and not provided access to enjoy the privilege of national examination and (driven by the parents' decisions) choose to end their educations as they lose an opportunity to obtain equal academic certifications.

Many institutions, however, argue that this exclusion practice can be translated as the government's initiative to ease the learning burden for disable students (Ediyanto, Atika, Kawai, and Prabowo, 2017). While this statement seems true at face value, it, if being deeply scrutinized, is 
Khasbani, EduLite: Journal of English Education, Literature, and Culture

misleading because the practice can create an undesirable consequence on the school level by compromising the quality of teaching instruction in academic environments. As a type of summative assessment, large-scale tests like Indonesian national examination functions as an evaluator to gauge the overall quality of the pedagogical instructions (Biggs, 2006). By conducting such an assessment, the stakeholder will be able to reflect the attainment of national education aims at the end of school years. That said, without the result of the national examination, school practitioners and stakeholders would lack primary information they can use to evaluate the overall quality of the academic process. They will not be able to accurately define whether students have met the intended classroom outcome and decide a better plan for inclusive classroom instructions in the following academic years.

In a more general inclusive context, some teachers, as witnessed by Poernomo (2016), reported that the unavailability of a definite accommodation policy had exerted an influence on the teaching and learning atmosphere in classrooms. These practitioners argued that little information of the assessment system has negatively affected their teaching attitudes. They frequently felt uncertain on how to accommodate inclusive students. They were unable to align the SwD's learning styles with classroom's goals, learning resources and the scoring system in the national examinations. This situation, while becoming a proof of Smith's (2000) assertion that teaching attitude plays a crucial role in defining successful teaching conduct, resonates Parasuram's (2006) idea that how teachers behave in front of their students' is mostly determined by outside variables like government policy and academic regulations.

\section{CONCLUSION}

With all above explanations, a demonstrative conclusion that one could propose regarding the application of accommodation in Indonesia is that the practice is still far from being perfect and done without having an adequate level of validation and definite regulation. Reconsideration and revision are thus still needed to increase the integrity of this accommodative practice. Taking into consideration the misconduct, social and academic implications issue of the high-stakes examination, a possible suggestion this paper could offer for better conduct of accommodation is providing well-formulated regulation that can be implemented by employing differential boots hypothesis, maximum potential thesis, and accommodative response format.

\section{'Differential Boost' and 'Maximum Potential Thesis'}

Providing clear guidance is a pivotal aspect of a test accommodation. Fuchs and Fuchs (2001) contended that the presence of a definite and standard principle in the accommodation can benefit test providers by increasing representative level of assessment outcomes and valid participation of test takers. Regarding this instance, the Indonesian government, as an addition to the attempt to increase the inclusion rate in national assessment, should also strive to narrow the performance gap between SwD and regular students in the test. The authority should have mentioned detailed and precise information on accommodation procedures in their regulation. The 
information should comprise a mechanism of how the accommodations are formulated. According to Tindal (1998) a well-formulated test accommodation is the one that improves the score of accommodated students higher than when it is applied to regular students. This conception is generally termed as differential boost in the academic research (Fuchs \& Fuchs, 2001). Along the same line, Zuriff (2000) also postulates the Maximum Potential Thesis as a critical requirement of an accommodation. The thesis generally refers to the ability of accommodation to ensure that students without disabilities will not be put in a disadvantaged situation by any given accommodation because they have employed their highest ability (maximum potential) under standard test regulation.

As can be seen from above discussions, Indonesian government appears to have not employed those two conceptions effectively in their accommodations. Some practices, such as providing visually impaired students with oral accommodations and removing teacher assistance for hearing problem students, seem to violate the value of the above conceptions. While the initial purpose of the national examination attempts to test students' reading ability (Ministry of Education, 2016), giving them oral assistance will not representatively accommodate the aim of the examination because students will rely on their listening ability most, if not all, of the time during the test. Removing teachers' assistance for hearing-impaired students can also cause construct-irrelevant barriers emerge during the testing. Students might not be able to show their maximum performance not because they lack ability but more because they cannot comprehend the test instructions and there is no assistance present to help them solve the problem.

\section{Accommodative Response Formats}

It should be noted that the central facet of test accommodation does not only facilitate how students understand the test questions. It, at the same time, also accommodates how they give their responses (Abedi, 2017). Some schools in Indonesia have provided dictated response accommodation where students spell out their answers and teachers mark the sheet. However, this practice alone is far from sufficient to help SwD on their testing for two different reasons. The first one is because employing teachers to help students mark the sheet can be impractical in the situation where the number of SwD exceed the number of assisting teachers. The other is because inclusive students frequently face barriers in marking their answer due to the complexion of the answer sheet that comes with Scantron form.

Scantron form, as its name tells, is a type of scanned answer sheet which requires students to mark their answer by filling in the bubble on the sheet. The use of Scantron is popular among multiple-choice assessment like that of Indonesian national examination. However, its practice for disabled students, especially those with mobility and cognitive challenge, is often disapproved on the ground that bubble sheet requires students to employ their visual and motoric disabilities to mark, locate and transfer an answer and it makes student with mobility and visual impairment more vulnerable to commit unnecessary mistake due to inaccuracy in marking procedure (Potter, Lewandowski, \& Spenceley, 2016). One of the conventional alternatives offered 
Khasbani, EduLite: Journal of English Education, Literature, and Culture

to mitigate the issue is allowing students to mark their answer directly on the test booklet. It has been scientifically observed that asking students to mark their choice on the test paper improve the number of questions answered and the number of the correct responses. Potter, Lewandowski, and Spenceley (2016) found on the study involving 109 undergraduate students that altering response format on an assessment significantly increased the number of questions the students answered while at the same time also allowed students to answer more question correctly. The findings of the study highlighted that the participants preferred to write their answers directly rather than circle the answers in the bubble sheet.

It is suggestive, based on the stated empirical evidence, that Indonesia government should start to consider utilising this marking response approach as the alternative of marking format. With paper-based assessment as the primary mode of test-taking in Indonesian national examination, it seems that this accommodation will face no significant administrative barriers. Students will only need to mark their choice in their sheet without having to mark the bubble in a careful manner to make sure that it can be appropriately scanned. Not only can this practice save students' time it can also minimise the error in marking process for students with mobility challenges.

\section{REFERENCES}

Abedi, J. (2009). Computer Testing as a Form of Accomodation for English Language Learners. Educational Assessment, 195-211.

Abedi, J. (2017). Utilizing Accommodations in Assessment. In E. Shohamy, \& N. H. Hornberger (Eds.), Language Testing and Assessment: Encyclopedia of Language and Education (Third ed., pp. 303-322). Cham: Springer.

Abedi, J., \& Lord, C. (2001). The Language Factor in Mathematics Tests. Applied Measurement in Education, 14(3), 219-234.

Abedi, J., Lord, C., \& Hofstetter, C. H. (1998). Impact of Selected Background Variables on Students' NAEP Math Performance (CSE Technical Report No.478). Los Angeles: University of California Center for the Study of Evaluation/National Center for Research on Evaluation, Standards, and Student Testing.

Ainscow, M. (2012). Moving Knowledge Around: Strategies for Fostering Equity within Educational System. Journal of Educational Change, 13, 289-310.

Antara, A. (2017, April 10). Meski Patah Tulang, Siswa SLB ini Tetap Semangat Ikuti Ujian Nasial [Despite the Fractures, A student in this Inclusive School is still Enthusiastic about the National Examination]. Retrieved 10 09, 2018, from Okezone News: https://news.okezone.com/read/2017/04/10/65/1663707/meskipatah-tulang-siswa-slb-ini-tetap-semangat-ikuti-ujian-nasional

Aprilia, I. D. (2017). Flexible Model of Special Education Services in Inclusive Setting Elementary School. Journal of ICSAR, 1(1), 50-54. 
Biggs, J. (2006). Assessment and Classroom Learning: A Role for Summative Assessment? Assessment in Education; Principles, Policy \& Practice , 103110.

Bolt, S. E., \& Thurlow, M. L. (2004). Five of the Most Allowed Testing Accomodations in State Policy. Remedial and Special Education, 25(3), 141-152.

Cahalan-Laitusis, C. (2004). Accomodations on High-stakes Writing Tests for Students With Disabilities. Princeton: Research Publications Office.

Christiyaningsih. (2017, March 18). Pertuni Tingkatkan Akses Penyandang Tunanetra ke Perguruan Tinggi [Pertuni Increases the Access of Visibility Impaired Graduate to Universities]. Retrieved May 11, 2018, from Republika:

http://www.republika.co.id/berita/nasional/umum/17/03/18/omzb0m 384-pertuni-tingkatkan-akses-penyandang-tunanetra-ke-perguruantinggi

Deslatama, Y. (2017, April 11). Perjuangan SIswa Berkebutuhan Khusus Jalani UN di Hari Pertama. Retrieved April 09, 2018, from Liputan 6: https://www.liputan6.com/regional/read/2916165/perjuangan-siswaberkebutuhan-khusus-jalani-un-di-hari-pertama

Detik News. (2012, April 23). Repot! Siswa Tuna Netra di Yogya Kerjakan Soal UN tak Berhuruf Braile [Complicated! Sight-challenged Students in Inclusive Schools in Yogyakarta are not Provided with Braille Question Papers]. Retrieved May 11, 2018, from Detik News: https://news.detik.com/berita/1898921/repot-siswa-tuna-netra-diyogya-kerjakan-soal-un-tak-berhuruf-braile

Ediyanto, Atika, I. N., Kawai, N., \& Prabowo, E. (2017). Inclusive Education in Indonesia from the Prespective of Widyaiswara in Centre for Development and Empowerment of Teachers and Education Personnel of Kindergartens and Special Education. Indonesian Journal of Disability Studies (IJDS), 04(02), 104-116.

Elliott, S. N., \& Marquardt, A. M. (2004). Extended Time as an Accomodations on a Standardized Mathematics Test: An Investigation of Its Effects on Scoresfor Students with Variying Mathematic Skills. Exceptional Children, 9(4), 349-367.

Felicia, N., \& Ramli, D. P. (2017). Country Case Study Prepared for the 2017/8 Global Education Monitoring Report Accountability in Education:Meeting Our Commitments: Accountability in Education Sector in Indonesia. Jakarta, Indonesia: UNESCO.

Fuchs, L. S., \& Fuchs, D. (2001). Heping Teachers Formulate Sound Test Accommodation Decisions for Students with Learning Disabilities. Learning Disabilities Research \& Practices, 16(3), 174-181.

Indonesian National Regulation. (2003). Sistem Pendidikan Nasioanl [National Education System). Jakarta, Indonesia: Author. 
Khasbani, EduLite: Journal of English Education, Literature, and Culture

Indrakrista, N. B. (2014, March 03). Tahun Ini Soal UN untuk Siswa Tunanetra Menggunakan Huruf Braille [This Year Visually Impaired Students Will be Provided with. Retrieved May 11, 2018, from Tribun Joga: http://jogja.tribunnews.com/2014/03/03/tahun-ini-soal-un-untuksiswa-tunanetra-menggunakan-huruf-braille

Indriawati, P. (2013). Implementasi Kebijakan Tugas Guru Pembimbing Khusus pada Pendidikan Inklusif di SD Negeri se-Kecamatan Junrejo Batu [The Implementation of Special Supervising Teacher Policy in Inclusive Schools of Junrejo Batu District]. Jurnal Kebijakan dan Pengembangan Pendidikan, 1(1), 49-55.

Lambert, R., \& Tan, P. (2017). Conceptualizations of Students with and without Disabilities as Mathematical Problem Solvers in Educational Research: A Critical Review. Education Science, 7(51), 1-18.

Lang, S. C., Kumke, P. J., Ray, C. E., Cowell, E. L., Elliott, S. N., Kratochwill, T. R., \& Bolt, D. M. (2005). Consequences of Using Testing Accomodations: Student, Teacher, and parent Perceptions of and Reactions to Testing Accomodations. Assessment for Effective Intervention, 31(1), 49-62.

Li, H., \& Suen, H. K. (2012). Are Test Accommodations for English Language Learners Fair? Language Assessment Quarterly, 9(3), 293-309.

Lindahl, R. (2006). The Right of Education in a Globalized World. Journal of Studies in International Education, 10(1), 5-26.

Lovett, B. J. (2010). Extended Time Testing Accommodation for Students With Disabilities: Answer to Five Fundamental Answers. Review of Educational Research, 80(4), 611-638.

Lovett, B., \& Lewamdowski, L. J. (2014). Testing Accommodations for Students with Disabilities: Research-Based Practice. Washington, DC: APA Books.

Mahendra, A. P. (2017, May 04). Peserta UN SMPLB Kesulitan Pahami Soal [Student in Inclusive Junior High School Face Difficulty in Understanding the High-Stake Examination Questions]. Retrieved May 09, 2018, from Bali Tribune: http://balitribune.co.id/content/peserta-un-smplbkesulitan-pahami-soal

Ministry of Education. (2009). Pendidikan Inklusif Bagi Peserta Didik yang Memiliki Kelainan dan Memiliki Potensi Kecerdasan dan/atau Bakat Istimewa [Inclusive Education for Students with disability and intelectual giftedness]. Jakarta, Indonesia: Ministry of Education .

Ministry of Education. (2015). Prosedur Operasional Standar Penyelenggaraan Ujian Sekolah/Madrash Pada Sekolah Dasar/Madrasah Ibtidaiyah, Sekolah Dasar Luar Biasa dan Penyelenggaraan Program Paket A/ULA [The Standard Operational Procedure of National Examination on Primary School/Islam. Jakarta, Indonesia: Kepala Penelitian dan Pengembangan Kementerian Pendidikan dan Kebudayaan.

Ministry of Education. (2016). Gambaran Sekolah Inklusif di Indonesia: Tinjauan Sekolah Menengah Pertama [The Description of Inclusive Schools 
in Indonesia: Junior High Schools Overview]. Jakarta, Indonesia: Pusat Data dan Statistik Pendidikan dan Kebudayaan.

Ministry of Education. (2017). Statistik Sekolah Luar Biasa (SLB) 2016/2017 [Inclusive School Statistics 2016/2017]. Jakarta, Indonesia: Pusat Data dan Statistik Pendidikan dan Kebudayaan.

Ministry of Health. (2014). Penyandang Disabilitas Pada Anak /CHildren With Disabilities]. Jakarta, Indonesia: Pusat Data dan Informasi Kementrian Kesehatan RI.

Parasuram, K. (2006). Variables that Affect Teachers' Attitudes Towards Disability and Inclusive Education in Mumbai, India. Disability \& Society, 21(3), 231-242.

Phillips , S. E. (1994). High-stake Testing Accomodation: Validity Versus Disabled Right . Applied Measurement in Education, 93-120.

Pitoniak, M. J., \& Royer, J. M. (2001). Testing Accomodation for Examinees with Disabilities: A Review of Psychometric, Legal, and Social Policy Issues. Review of Educational Research, 71(1), 53-104.

Poernomo, B. (2016). The Implementation of Inclusive Education in Indonesia: Current Problems and Challenges. American International Journal of Social Science, 5(3), 144-150.

Potter, K., Lewandowski, L., \& Spenceley, L. (2016). The Influence of a Response Format Test Accomodation for College Students With and Without Disabilities. Assessment \& Evaluation in Higher Education, 41(7), 996-1007.

Purbani, W. (2013). Equity in the Classroom: The System and Improvement of Inclusive Schools in Yogyakarta, Indonesia. US_China Education Review $B, 3(7), 507-518$.

Qudsyi, H., \& Putri, M. I. (2016). Self-efficacy and Anxiety of National Examination among High School Students. Procedia Social and Behavioral Sciences, 217, 268-275.

Ramdani, D. N. (2016, May 09). Di Kabupaten Cianjur, Lulusan SLB Masih Sulit Mendapat Kerja yang Layak [In Cianjur DIstrict, Inclusive School Gradutes Cannot Get an Appopiate Job]. Retrieved May 11, 2018, from Tribun Jabar: http://jabar.tribunnews.com/2016/05/09/di-kabupatencianjur-lulusan-slb-masih-sulit-mendapat-kerja-yang-layak

Sheehy, K., Budiyanto, B., Kaye, H., \& Rofiah, K. (2017). Indonesian Teachers' Epistemological Beliefs and Inclusive Education. Journal of Intellectual Disabilities, 1-18.

Sireci, S. G., Scarpati, S. E., \& Li, S. (2005). Test Accomodations for Students with Disabilities: An Analysis of the Interaction Hypothesis. Review of Educational Research, 75(4), 457-490.

Smith, M. G. (2000). Secondary Teachers' Perceptions Toward inclusion of Students with Severe Disabilities. National Association of Secondary School Principals (NASSP) Bulletin, 84(613), 54-60. 
Khasbani, EduLite: Journal of English Education, Literature, and Culture

Stangvik, G. (2010). Special Education in Society and Cuture: Comparative and Developmental Perspectives. European Journal of Special Needs Education, 25, 349-358.

Sunardi, Yusuf, M., Gunarhadi, Priyono, \& Yeager, J. L. (2011). The Implementation of Inclusive Education for Students With Special Needs in Indonesia. Excellence in Higher Education, 2, 1-10.

Tindal, G. (1998). Models for Understanding Task Comparability in Accomodated Testing. Eugene, OR: Behavioral Research and Teaching.

UNESCO. (2008). Country Report: Indonesia: Indonesian Public Policies on Inclusive Education. Retrieved Mey 05, 2018, from www.ibe.unesco.org/National_Reports/ICE_2008/indonesia_NR08.pdf

Yayasan Mitra Netra. (2012, May 09). Tragedi Ujian Nasional di SLB-A. Retrieved May 11, 2018, from https://mitranetra.or.id/2012/05/09/tragedi-ujian-nasional-di-slb-a/

Young, J. W., \& King, T. C. (2008). Testing Accomodations for English Language Learners: A Review of States and DIstrict Policies. New York: The College Board. Retrieved May 09, 2018, from https:/ / files.eric.ed.gov/fulltext/ED563044.pdf

Yusraini. (2013). Kebijakan Pemerintah terhadap Pendidikan Inklusif. Media Akademika, 27-40.

Zuriff, G. E. (2000). Extra Examination Time for Students with Learning Disabilities: An Examination of the Maximum Potential Thesis. Applied Measurement in Education, 13(1), 99-117. 